\title{
Jehan Du Pré, Le Palais des nobles Dames (Lyon, 1534)
}

\section{Dario Cecchetti}

\section{(C) OpenEdition}

\section{Journals}

\section{Edizione digitale}

URL: http://journals.openedition.org/studifrancesi/9453

DOI: $10.4000 /$ studifrancesi.9453

ISSN: 2421-5856

\section{Editore}

Rosenberg \& Sellier

\section{Edizione cartacea}

Data di pubblicazione: 1 décembre 2007

Paginazione: 636-637

ISSN: 0039-2944

\section{Notizia bibliografica digitale}

Dario Cecchetti, «Jehan Du Pré, Le Palais des nobles Dames (Lyon, 1534)», Studi Francesi [Online], 153 (LI | III) | 2007, online dal 30 novembre 2015, consultato il 12 janvier 2021. URL: http://

journals.openedition.org/studifrancesi/9453 ; DOI: https://doi.org/10.4000/studifrancesi.9453

Questo documento è stato generato automaticamente il 12 janvier 2021.

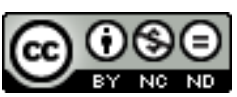

Studi Francesi è distribuita con Licenza Creative Commons Attribuzione - Non commerciale - Non opere derivate 4.0 Internazionale. 


\title{
Jehan Du Pré, Le Palais des nobles Dames (Lyon, 1534)
}

\author{
Dario Cecchetti
}

\section{NOTIZIA}

JEHAN DU PRÉ, Le Palais des nobles Dames (Lyon, 1534), édition établie, présentée et annotée par Brenda DUNN-LARDEAU, Paris, Champion, 2007 («Textes de la Renaissance», 115), pp. 492.

1 Durante un sogno, Noblesse feminine invita un autore a seguirlo nei tredici loci di un palazzo, che comprende varie camere e un giardino ove donne famose di ogni tempo e di ogni luogo sono raggruppate sulla base delle imprese o delle qualità che le hanno immortalate. Il racconto di questo sogno costituisce la materia dei 5667 versi del Palais de nobles Dames, dedicato nel 1534 da Jehan Du Pré a Marguerite de Navarre. Il testo si ricollega alla querelle des femmes e si situa in quella tradizione dei repertori di donne illustri e dei cataloghi di dame virtuose, influenzati dal De claris mulieribus boccacciano e dai suoi volgarizzamenti francesi. La struttura del Palais si ricollega anche con la tradizione letteraria del Temple dei Rhétoriqueurs, sebbene non vi si ritrovino né l'aspetto caratteristico del prosimetro né le finalità di istituzione e di difesa della lingua francese. Così pure il Palais si ricollega, per la disposizione del contenuto, con la tradizione delle arti della memoria, che si fondano sulla combinazione di loci e di immagini, in modo tale che l'orator nel costruire il suo discorso si trovi nelle condizioni di chi, attraversando le stanze di un edificio, segua un ordine che è quello degli argomenti che deve trattare. In questo senso Jehan Du Pré organizza metodicamente la sua materia, così da istituire tutta una serie di richiami alle opere dell'antichità in funzione della memorizzazione. L'introduzione illustra tutti gli aspetti strutturali ed elenca i principali temi affrontati in questo teatro della memoria: la bellezza femminile e le virtù di verginità, castità, fedeltà e temperanza; il ruolo specifico della maternità; le capacità esplicate anche in campi più propriamente maschili, come lo sport e la vita intellettuale; la valorizzazione della donna anziana, cosa eccezionale per l'epoca. 
L'edizione riproduce le xilografie originali, il che è di grande interesse per i rapporti che si possono istituire con l'emblematica. Eccellente, ben strutturato e ampio il glossario. 